\title{
Advances in qualitative comparative analysis (QCA): Application of fuzzy set in business and management research
}

\author{
Document Version \\ Accepted author manuscript
}

Link to publication record in Manchester Research Explorer

Citation for published version (APA):

Ott, U., Sinkovics, R. R., \& Hoque, S. F. (2018). Advances in qualitative comparative analysis (QCA): Application of fuzzy set in business and management research. In C. Cassell, A. L. Cunliffe, \& G. Grandy (Eds.), The SAGE Handbook of Qualitative Business and Management Research Methods (pp. 414-430). Sage Publications Ltd. https://us.sagepub.com/en-us/nam/the-sage-handbook-of-qualitative-business-and-management-researchmethods/book245704

\section{Published in:}

The SAGE Handbook of Qualitative Business and Management Research Methods

\section{Citing this paper}

Please note that where the full-text provided on Manchester Research Explorer is the Author Accepted Manuscript or Proof version this may differ from the final Published version. If citing, it is advised that you check and use the publisher's definitive version.

\section{General rights}

Copyright and moral rights for the publications made accessible in the Research Explorer are retained by the authors and/or other copyright owners and it is a condition of accessing publications that users recognise and abide by the legal requirements associated with these rights.

\section{Takedown policy}

If you believe that this document breaches copyright please refer to the University of Manchester's Takedown Procedures [http://man.ac.uk/04Y6Bo] or contact uml.scholarlycommunications@manchester.ac.uk providing relevant details, so we can investigate your claim.

\section{OPEN ACCESS}




\title{
Advances in Qualitative Comparative Analysis (QCA): Application of fuzzy set in business and management research
}

\author{
Ursula Ott, Kingston University, UK \\ Rudolf R. Sinkovics, The University of Manchester, UK (*) \\ Samia Ferdous Hoque, The University of Manchester, UK
}

\section{This is an Author's Original Manuscript (AAM) of a book-chapter published in The Sage Handbook of Qualitative Business and Management Research Methods, published by Sage. To cite:}

Ott, Ursula, Rudolf R Sinkovics, and Samia Ferdous Hoque (2018), "Advances in qualitative comparative analysis (QCA): Application of fuzzy set in business and management research," in The Sage handbook of qualitative business and management research methods, Catherine Cassell, Ann L Cunliffe, and Gina Grandy (Eds.). London: Sage Publications. pp. 414-430

\author{
$\underline{\text { Ursula Ott }}$ \\ Professor of International Business \\ Kingston University London \\ Kingston Hill Campus, Surrey, KT2 7LB, United Kingdom \\ U.Ott@kingston.ac.uk \\ http://business.kingston.ac.uk/staff/professor-ursula-f-ott
}

\section{Rudolf R. Sinkovics (* corresponding author)}

Professor of International Business

The University of Manchester, Alliance Manchester Business School

Booth Street West, Manchester M15 6PB, United Kingdom and Lappeenranta University of Technology, Finland

Phone: +44 (161) 3068980

Rudolf.Sinkovics@manchester.ac.uk

http://www.manchester.ac.uk/research/rudolf.sinkovics

http://orcid.org/0000-0002-4471-5054

$\underline{\text { Samia Ferdous Hoque }}$

Research Associate in International Business and Management The University of Manchester, Alliance Manchester Business School

Booth Street West, Manchester M15 6PB, United Kingdom

Samia.Hoque@manchester.ac.uk

https://www.research.manchester.ac.uk/portal/samia.hoque.html http://orcid.org/0000-0002-5669-4326 


\section{Advances in Qualitative Comparative Analysis (QCA): Application of fuzzy set in business and management research}

\section{Introduction}

Following from the seminal book of Charles Ragin in 1987, qualitative comparative analysis (QCA) has gained increasing acceptance in social science research for systematic comparative case analysis (Rihoux 2006). The QCA approach is built upon the set-theoretic comparative technique, primarily Boolean algebra, and has been introduced as a "synthetic strategy" for integrating the strengths of qualitative and quantitative methods while overcoming the key concerns inherent in both the approaches (Ragin 1987:84). BergSchlosser and De Meur (2009:17) define it as "a nonlinear, non-additive, non-probabilistic conception that rejects any form of permanent causality and that stresses equifinality (different paths can lead to the same outcome), complex combinations of conditions, and diversity". The Boolean or crisp-set technique is the first QCA version, while fuzzy set technique is a more recent extension (Ragin 2000, 2008a). Unlike crisp sets that assign dichotomous membership, fuzzy sets permit partial membership in a category, meaning both causal and outcome variables can be multichotomous (Stokke 2007).

Although social science research has a long-lasting tradition of prioritising variableoriented quantitative methods, the popularity of case-oriented qualitative techniques has also been developing at a steady pace (Ragin 1994; Ragin and Becker 1992). Nevertheless, caseoriented qualitative research is often criticised to be weak in terms of external validity for placing overly emphasis on the specifics of an individual case. The internal validity is also in question considering the method's inability to choose between various possible or plausible explanations of a phenomenon. This problem, regarded as degrees-of-freedom or 'small-N problem', means that "there are too few observations relative to the set of variables under consideration to determine the relative significance of the causal factors" (Stokke 2007:501). Qualitative researchers tend to compensate for this issue by paying attention to complexity and depth in a given case (Ragin and Becker 1992). In this respect, Ragin (1987:51) argues that the term "small-N problem" misrepresents the challenge confronting case-oriented research, since "it is not the number of relevant cases that limits the selection of method... but the nature of the method that limits the number of cases and the number of different causal conditions that the investigator is able to consider." The QCA technique is designed to overcome this small-N problem and is equipped to handle only a limited number of cases. The approach will not only increase the number of cases but also will find similarities and differences across cases on a configuration of causal conditions in order to identify patterns with possibilities for modest level generalisation (Rihoux and Ragin 2009).

Although initially applied in political and historical sciences, QCA offers particular promise to organisational researchers (Rihoux and Ragin 2009). Fiss (2007:1180) argues that "organisations are best understood as clusters or interconnected structures and practices, rather than as modular or loosely coupled entities whose components can be understood in isolations". The QCA approach is fundamentally based on the idea that the patterns and attributes will exhibit different features and lead to different outcomes depending on how they are arranged. Therefore, the approach stresses nonlinearity and synergy of depth and 
breadth within and across cases (Ragin 2014) which is typical of real-world qualitative research (cf. Sinkovics and Alfoldi 2012). However, this contrasts with a long-tradition of organisational research in the application of econometric or statistical tools which imply linearity.

Against this context, the use of QCA in the field of management is beneficial for the understanding of complex management phenomena. It combines qualitative investigation with quantitative analysis. A recent Journal of Business Research special issue (Roig-Tierno, Huarng, and Ribeiro-Soriano 2016) published forty six articles on QCA and illustrates the potential for management research. In their lucid overview article, Seny Kan et al. (2016) show that 95 articles use QCA in management research. Their classification highlights its use in general management, marketing, innovation, strategy, human resources, organization studies and operational research. The result of their article suggests that researchers apply QCA to four management situations: the internal environment, the external environment, links within and between these environments and the optimal way to question management phenomena. The use of QCA in the special issue extends the application to entrepreneurial activity, organizational strategy and management performance (Roig-Tierno, Huarng, and Ribeiro-Soriano 2016).

To this end, the purpose of this chapter involves presenting, discussing and explaining the QCA method and highlighting the application of the method in business and management research. The chapter is, therefore, organised in the following way: first, we present the QCA approach discussing its history, epistemology and key methodological features; second, we shed light on the progress in the application of QCA approach by highlighting the patterns thus far; and finally, we detail the method for its application and exemplify the conceptual considerations presented earlier. The chapter concludes with a summary and suggestions regarding future avenues for using QCA approach in the field of management research.

\section{Background on QCA and fsQCA}

QCA is the umbrella name for two main types of techniques: crisp set qualitative comparative analysis (csQCA) and fuzzy set qualitative comparative analysis (fsQCA) (Rihoux 2006). Both the methods are designed to transfer subjective data into numeric ones by assigning values of either 0 and 1 (crisp) or in-between 0 and 1 (fuzzy). Crisp set qualitative comparative analysis (csQCA) was the original version of QCA and is built upon the binary language that George Boole developed in the mid-1800s. The Boolean algebra is also the mathematical basis of computer technology. Boolean algebra does not manipulate numbers but rather systematizes logical expressions in order to sort data and create a list of the configurations of circumstances associated with a given outcome (Stokke 2007). The application of crisp logic for systematic comparative procedures dates back to $18^{\text {th }}$ and early $19^{\text {th }}$ century primarily in natural sciences (Rihoux and Ragin 2009).

Fuzzy set qualitative comparative analysis (fsQCA) is a much later extension to QCA and is built upon the fuzzy set theory (Ragin 2008a). The introduction of fuzzy set theory dates back to the sixties with the publication of seminal articles by Zadeh (1965) and Goguen (1969). Zimmermann (2010) highlighted that the development of fuzzy set has mainly been in two key areas: first, as a formal theory with increasing sophistication and specification being added to the original ideas and concepts of Zadeh (1965); and secondly, as fuzzyoriented application in problem solving and research. The acceptance of fuzzy set gained momentum between 1960s and 1970s with its first application in controlling technological processes. The successful use of fuzzy rule based system, namely fuzzy control, in the 
manufacturing of washing machine, video cameras, subway trains and heavy machineries by Japanese technology firms triggered the interest in further application of the method in scientific research during 1980s.

The application of classical set theory in social science research followed from a seminal volume by Charles Ragin (1987). In a series of publications (e.g. Ragin 1987, 1994), Ragin introduced the use of crisp set qualitative comparative analysis in social science research. During the 1980s and 1990s, csQCA was mostly applied in political science (comparative politics) and historical sociology (welfare state studies) research. As a result, csQCA was initially adopted in the social science as a tool for macro-level studies involving entire societies, economies, states or other complex social and cultural formations. The organisational researchers have applied the method in meso-level (i.e. firm-level) studies in recent years (Rihoux and Ragin 2009).

Zadeh (1965) argues that fuzziness is contained in human language including human judgement, evaluation and decisions. Drawing upon this argument, Ragin (2000) contends that fuzzy set theory can be a powerful tool to capture the fuzzy nature of human language that remained difficult thus far through the application of dichotomising techniques of csQCA. Therefore, built on crisp sets csQCA, the key strength of fsQCA lies in providing the variance of the observations.

Developed around the Boolean binary logic (scores of 0 and 1), csQCA assigns membership to cases across a configuration of condition, in which a score of ' 1 ' reflects 'full membership' and '0' reflects 'no membership' in a specific set of conditions. While csQCA assigns dichotomous membership ('yes $=1$ ' or ' $\mathrm{no}=0$ ') to the cases across a set of conditions, fsQCA addresses degree of membership in sets by assigning intermediary numbers between 0 and 1 (Rihoux and Ragin 2009). Ragin (2008a:30) claims "fuzzy sets have many of the virtues of conventional interval and ratio-scale variables, but at the same time they permit qualitative assessment." For instance, in the fsQCA approach, a membership score of 1.0 indicates full membership in a set; scores close to 1.0 (e.g. 0.8 or 0.9 ) indicate strong but not quite full membership in a set; scores less than 0.5 but greater than 0.0 (e.g. 0.2 or 0.3 ) indicate that objects are more "out" than "in" a set, but still weak members of the set; a score of 0.0 indicates full non membership in a set. The score 0.5 reflects maximum ambiguity or fuzziness in the assessment of whether a case is more in or out of a set. Thus the variables (condition and outcome) can be calibrated aiding the construction of the truth table through use of substantial theoretical knowledge and evidences from cases (Rihoux and Ragin 2009). As pointed by Ragin and Amoroso (2011), fuzzy sets are simultaneously quantitative and qualitative: full membership and full non-membership are qualitative states, while varying degrees of membership are quantitative measurements ranging from more out (closer to value $0)$ to more in (closer to value 1 ).

Epistemologically, the QCA approach (both csQCA and fsQCA) is a middle way between the case-oriented qualitative research and variable-oriented quantitative research (Rihoux 2006). On the one hand, the qualitative approach emphasises the complexity of a social phenomenon and offers in-depth detail about small number of cases/instances. On the other hand, quantitative approach is interested in generalisation and finding patterns that are evident in large number of cases/instances. One of the key criticisms of the quantitative approach relates to its difficulty in addressing actors' underlying motives to certain responses, observing the subjectivities and sequences of the events and deriving the causal connections. Qualitative methods, by contrast, excel in these areas. However, with a qualitative approach, it is difficult to claim that the findings are generalizable due to its reliance on small number of cases. Despite this methodological divide, qualitative and 
quantitative approaches could be complementary and mutually dependent. For instance, qualitative researchers often cite general patterns that they have learned from previous quantitative studies in order to explain case specific phenomena. On the other hand, quantitative researchers also cite unobserved case-level mechanisms to explain the cross-case patterns they document. This complementarity and mutual dependence underpins the idea of building a bridge and finding a middle ground where concerns of both worlds can be met (Ragin 2000). The QCA approach offers this middle ground between the issue of generality as portrayed in quantitative study and complexity in qualitative study.

Ragin (1987) contends that the QCA approach resolves some of the methodological issues inherent in qualitative and quantitative approaches and strengthens the connection between the two approaches. QCA (and fsQCA) approach has its fundamental tie with caseoriented research, which has the unique strengths of understanding the cases within their context, the causations in conjunction and outcome as results of combination of conditions. While clutching these unique strengths of case-oriented approach, QCA is developed to formalise those by using Boolean algebra. Nevertheless, case-oriented researchers often claim that their findings are specific to individual cases and thus, faced with large number of cases, they find it difficult to sustain their attention to complexity and also to address the similarities and differences across many cases. By contrast, a variable-oriented approach is more interested in variables across large number of cases to find correlation between those, and in the process, the cases lose their identity and the context gets overlooked. While holding its case-oriented tradition, QCA is designed to handle larger number of cases, at the same time, examine the causal complexity in those cases by avoiding the simplifying principles of variable-oriented research. It is, therefore, a 'synthetic strategy' that is interested in both within-case and cross-case analysis (Ragin 2014:84). On the one hand, the emphasis on breadth as in variable-oriented approach is retained through analysis of more than just a handful of cases, which is seldom done in case-oriented research and on the other hand, the attention to depth is given by focusing exclusively on the specificity of individual cases and maintaining intimacy with the context (Rihoux and Ragin 2009).

Rihoux and Ragin (2009) had listed four key features of QCA: i) causality, complexity and parsimony; ii) modest generalisation; iii) ideas and theory and iv) data, replicability and transparency. Firstly, in QCA approach causation is typically understood conjecturally, as combinations of conditions. It is interested in causal complexity, which Ragin (2008a:23) defines as "a situation in which an outcome may follow from several different combination of causal conditions, that is, from different recipes". These configurations of causally relevant conditions are compared across cases to link those to outcomes (Ragin 2008a, 2014). The key tool for analysing causal complexity in QCA is the truth table, a tool that allows structure focused comparisons (the process of constructing a truth table is detailed in the methodology section). In comparative analysis, causal conditions do not compete with each other, as they do in variable-oriented analysis while deriving correlations; they rather act in combination to generate a specific outcome. Again, different combination of conditions may also lead to the same outcome, for example, different social forces leading to the emergence of welfare states in Western Europe (e.g. Alber 1995). Thus Rihoux and Ragin (2009:8) refer this characteristic as "multiple conjunctural causation" in which, the word "multiple" refers to the different paths to produce same outcome and "conjunctural" conveys that each path is a combination of conditions.

Secondly, the QCA approach allows comparing small to intermediate number of cases (referred as 'small-N' or 'intermediate-N' (Ragin 1987)) as configuration to identify similarities and differences across cases. The cases are compared in a truth table to identify the ones displaying identical configurations of causal conditions and the ones differing on 
one or more causally relevant conditions (Ragin 2014). This process allows finding patterns among low number of cases such as, 2 to intermediate number of cases, say 50 to 100 . Therefore, QCA is equipped to support "modest generalisation" in a small-N or intermediateN situation (Ragin 1987:31). This systematic comparative analysis facilitates formulating propositions which can then be applied to other similar cases (of course, with caution). However, the robustness of generalisation is greater in variable-oriented research allowing very broad generalisation (Rihoux and Ragin 2009).

Third, the QCA approach facilitates a dialogue between theory and cases. The cases are considered as a specific combination of properties within a specific context - a "whole entity', while in variable-oriented research, the cases and context are lost in the course of variable search and analysis (Ragin 2014). Therefore, the research needs to have in-depth understanding of the cases, which aids the identification and development of the configuration of the conditions. The cases are not randomly selected from a population rather are carefully selected in consultation with historians, country experts and others and each case are well known having an identity rather than being anonymous. Therefore, the process of selecting the understanding the cases are holistic and inductive. The choice of conditions also needs to be theoretically informed, which adds a deductive dimension to the QCA approach. The theoretical knowledge also contributes for the selection of the cases including the exceptions and outliers and also treatment of the contradictory configurations (i.e. the cases that display the same values on the condition variables but lead to different outcomes (Rihoux and Ragin 2009). The interpretation of the findings should also have to be derived from theoretical knowledge. With having both deductive and inductive aspects embedded in the process, QCA is equipped to generate mid-range theories (Rihoux 2006).

Finally, with the use of Boolean algebra, the QCA offers tools that are both formalised and replicable. The QCA allows assigning numbers to data that are originally subjective in nature and thus making the study replicable. The process of selection of variable, processing them and intervening during the analysis are transparent. The researcher has to constantly refer to the case and go back-and-forth which requires a rich data and theoretical knowledge. Thus the approach is not a mere mechanical and "push-button" oriented one rather requires researchers' constant engagement which makes the process more transparent (Rihoux and Ragin 2009).

\section{QCA in business and management research}

The rationale why researchers use QCA in management is that the complexity of the management phenomena and the understanding the management practices asks for more refined modes of investigation. An in-depth knowledge of the cases and a robust manner to analyse them. QCA has three variants - crisp-set, multi-value and fuzzy-set. Seny Kan et al. (2016) investigated the use of QCA in management research and found that in most articles it serves the renewal of the understanding of management situations. QCA can be positioned between exploration and hypothesis testing and it has an original role in strengthening knowledge generation through a dialog between case studies and theory. Finally, QCA is helpful in limiting the recurrence of mismatches between theory and methods in management research. The authors emphasize that the QCA has two forms of explanatory paths: 1) a specific management reality could have a multiplicity of causal paths - equifinality. 2) asymmetric nature of management phenomena. Overall, QCA offers the depth of qualitative research and a coherence for understanding the configurations of the antecedents leading to the outcome of a phenomenon. Many paths can lead to an outcome in managerial research. 
Seny Kan et al (2016) show that fuzzy set is the most common of the three variants of QCA and the studies were empirical, theoretical and methodological. Important for the use of cases is that the unit of analysis can be organization, individual, country or state. This chapter highlights the recent developments in QCA in management research and positions it in this respect.

The scope of small-N to full-N enables fsQCA to be used in qualitative and quantitative investigations. FsQCA in the latter is mostly used to complement quantitative findings in providing asymmetric relationships of the analysis. The fsQCA approach in qualitative research gives the robustness of the results and the generalizability of the findings. The critiques of qualitative research can be circumvented in this case, since validity, reliability and authenticity of the results are positioned in a more convincing way with fsQCA. With fsQCA the researcher can distinguish between necessary and sufficient conditions for the occurrence of managerial phenomena and by being able to do this, a central criticism of management research - the lack of actionability (Seny Kan et al, 2016) can be addressed.

Insert

Figure 1 about here

The use of fsQCA in business research can be considered in a more structured way after the publication of more than hundred articles. Seny Kan et al (2016) and Roig-Tierno et al. (2016) provide classifications of the articles using fsQCA in management research. Figure 1 above shows the frequency of fsQCA use in the respective functional areas of management.

Interviewing actors on different organizational levels helps to find out about organizational and managerial phenomena which need an exploratory approach for knowledge generation. Seny Kan et al (2016) moved away from a functional perspective and focussed on the four configurations below:

Internal environment. Mostly organizational structure and strategy papers use fsQCA for their investigation into procedures, strategies and performance.

External environment. The relationship of the actors with customers, suppliers, HQ, governmental bodies benefits from an in-depth analysis of the cases for managerial research.

Enterpreneurship activities. As a new approach towards understanding small enterprises, interviewing entrepreneurs shows a valid empirical and theoretical unit of analysis by focusing on the individual and the decision-making of business leaders.

Innovation and performance. This stream of research in fsQCA is important and transferred to many different levels from individual to country and shows the reliability of the findings in terms of necessary and sufficient conditions for the outcome.

The recent Special Issue of set theory (fsQCA) in the Journal of Business Research can be seen in structuring fsQCA in management according to entrepreneurial, organizational and performance configurations in management. The table below summarizes the extensive use of fsQCA in this respect.

Insert 
Figure 1: The use of fsQCA in management research (Seny Kan et al. 2016)
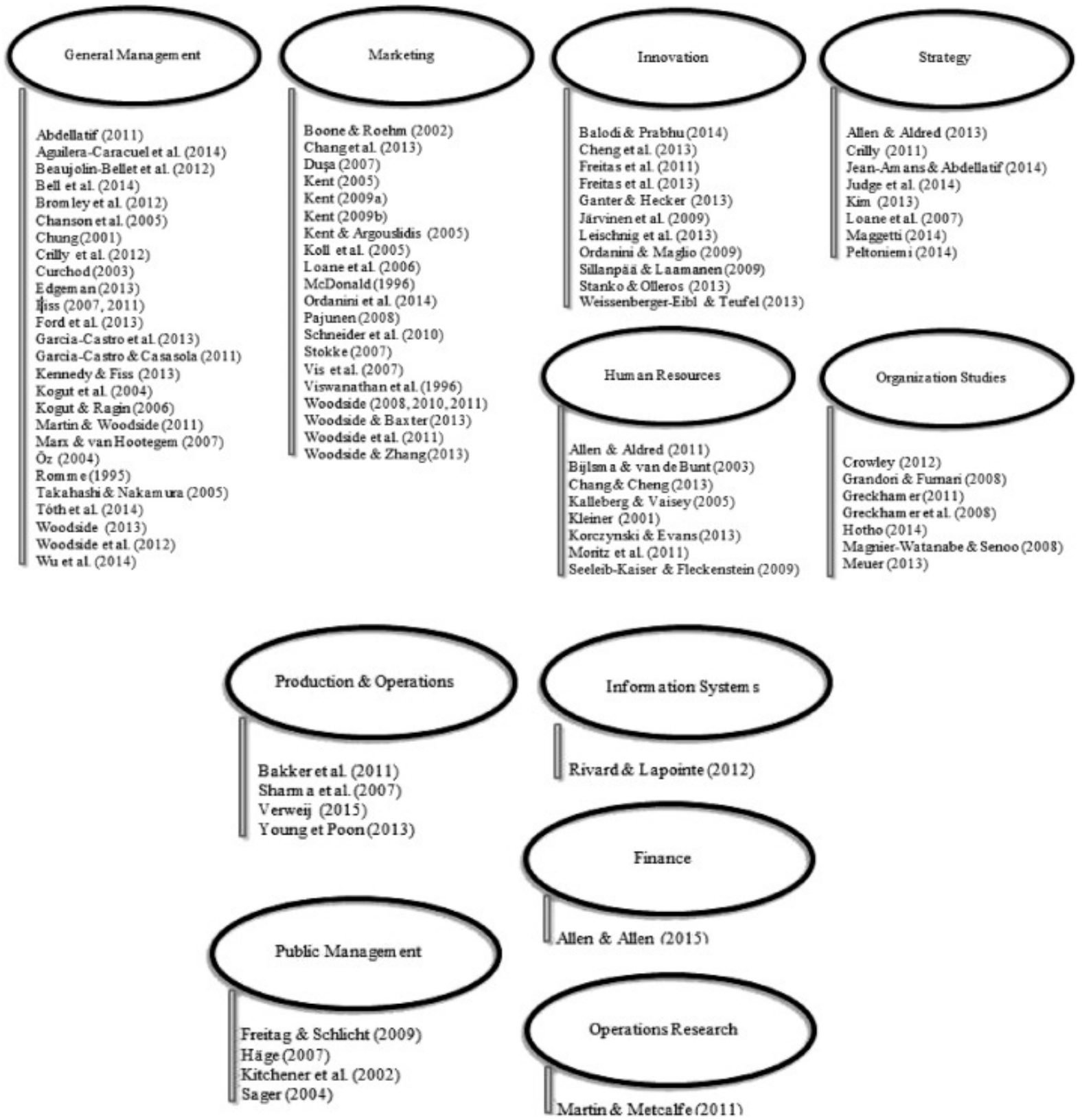

Table 1 about here

The applications for fsQCA are manifold and offer a research agenda for many years to come. The next section offers an example fsQCA application. 


\section{4 fsQCA application example}

This example uses Ragin's (2008b) manual for fsQCA software as a guide on how to work with the collected data and transfer it into fsQCA results. The example below goes back to Ragin (2008a) and Rihoux and Ragin (2009). This is especially beneficial, since the country comparisons chosen are an important approach to provide a classification and calibration for an introduction into fsQCA. The data is in general collected with an excel spreadsheet and then saved with comma separated (csv) format which will lead to the table below when starting the fsQCA program.

From interviewing to calibration, the data collection with interviews benefits from an indepth knowledge of the researcher. As Ragin (2008a) points out, the researcher needs to know the subject, interviews, theory and method well to be able to generate new insights with fsQCA. The number of interviews or cases can be from small $\mathrm{N}$ to medium $\mathrm{N}$. Large $\mathrm{N}$ are only used to compare quantitative studies (Regression models of symmetric relationships) with fsQCA (asymmetric relationships). The interview data can then be structured into themes which make up the conditions (antecedent, concurrent and consequential). The example below uses gross domestic product, manufacturing sector, strong unions etc. (macroeconomic conditions for country perspectives). The next step is the generation of a calibration table in which the qualitative results are translated into memberships of sets. Full membership in a set is considered at 1 and an empty set is 0 . All the grey levels in between will be positioned between break points $(0.5 ; 0.33$ and $0.67 ; 0.2,0.4,0.6$ and 0.8$)$. This is the important part for the transfer from qualitative to quantitative analysis. The Figure below shows therefore values between 0 and 1 .

Insert

Figure 2 about here

The table in figure 2 above shows the cases in the first column and the conditions generated from the calibration table. In this case $g d p f$ stands for affluent, inqf is substantial income inequality, manf is strong manufacturing sector, unf is strong unions and weakcv stands for weak class voting (Ragin, 2008, 75). To generate a truth table analysis, the user will need to go to 'Analyze' and then to 'Fuzzy Sets' and 'Truth Table Algorithm'. The screenshot below should guide the reader towards creating the truth table, which follows in two easy steps. The outcome condition will be chosen first and then the conditions leading to the outcome are then clicked into the causal condition section. Clicking on the run button will bring up the truth table.

Insert

Figure 3 and 4 about here

The truth table shows the causal conditions, the number of the cases with the combination, and the outcome condition as well as consistency values, for example let's take the first row with 3 cases or $25 \%$ covered by the joint set of gdpf and inqf and the empty cell 
for outcome and 0.95 for consistency. The truth table represents $2^{\mathrm{k}}$ rows (where k represents the number of causal conditions) which is a reflection of all possible combinations of causal conditions.

The outcome condition weakcv is blank and it is up to the researcher to determine the outcome for each configuration. Consistency values are shown in column consist and show the degree to which membership in that corner of the vector space is a consistent subset of the membership in the outcome (Ragin, 2008b, p. 77). After applying the frequency threshold of 1 to the data and reducing the table by the configuration that do not have any observations. The consistency threshold of 0.9 is selected and 1 is placed in the weakcv (outcome) column for configurations with 0.95 consistency and greater and 0 for cases with lower consistency.

Insert

Figure 5 about here

After constructing the truth table the researcher can the select 'Standard Analyses' and this leads to the provision of the complex, intermediate and parsimonious solutions. These are the logical remainders of the solution. Using the Specify analysis will lead to different outputs. The standard analysis is preferred however. The table below shows the output for the standard analyses.

Insert

Figure 6 about here

According to Ragin (2008b), the solution is here that weak class voting is a product of the high membership in the set of affluent countries and weak membership in strong unions.

FsQCA offers as well the possibility to show descriptive statistics, frequency analysis and cross-tab results. Below is the result for the fsQCA outcome of weak class voting shown as descriptive stats.

Insert

Figure 7 about here

\section{Conclusion}

The explanation, presentation and discussion of fsQCA for management and business research offers a tool which benefits this field of research to generate qualitative results and transfer these into rigorous quantitative findings. This chapter emphasises the relevance of this methodology and shows its applicability to real-life problems in a complex field such as business and management. The literature review therefore provides an insightful overview 
regarding the use of fsQCA. We hope that business and management scholars will follow up on the opportunities offered by this methodology. A good starting point is the literature offered by Ragin and colleagues, in terms of empirical application, the software offered as a free download at the University of Arizona, will prove invaluable.

This chapter highlights the possibility for researchers to see their qualitative results transferred into a quantitative framework. This allows the findings to be communicated differently, which will be appealing to quantitatively trained audiences. Organisational business questions are looking into asymmetrical relationships which coincide with real-life applications and the strength of fsQCA to provide answers in that respect. Regression analysis results, which have been used so far in management research and provide a symmetric solution to asymmetrical problems, can now be complemented with fsQCA findings.

The practical example in this chapter follows a step-by-step approach from data collection, calibration, truth table analysis to the necessary and sufficient conditions of the outcome. The researcher can also add descriptive statistics, which enable qualitative data to be shown in an equivalent manner to quantitative results.

This chapter argues that fsQCA offers qualitative research a tool which gives rigorous insights into problems, which consider the classification and analysis of actions and behaviour as well as the provision of equifinal solutions where many paths can lead to an outcome. The in-depth analysis of case-oriented research combined with rigour benefits the research questions of managerial phenomena.

\section{References}

Alber, Jens (1995), "A framework for the comparative study of social services," Journal of European Social Policy, 5 (2), 131-149. (DOI: 10.1177/095892879500500204).

Berg-Schlosser, Dirk and Gisèle De Meur (2009), "Comparative research design: Case and variable selection," in Configurational comparative methods. Qualitative comparative analysis (qca) and related techniques, Benoît Rihoux and Charles C. Ragin (Eds.). California: SAGE Publications, Inc. , 19-32.

Crilly, Donal (2011), "Predicting stakeholder orientation in the multinational enterprise: A mid-range theory," Journal of International Business Studies, 42 (5), 694-717. (DOI: 10.1057/jibs.2011.57).

Fan, Di, Lin Cui, Yi Li, and Cherrie J. Zhu (2016), "Localized learning by emerging multinational enterprises in developed host countries: A fuzzy-set analysis of Chinese foreign direct investment in Australia," International Business Review, 25 (1), 187203. (DOI: 10.1016/j.ibusrev.2014.12.005).

Fiss, Peer C. (2007), "A set-theoretic approach to organizational configurations," Academy of Management Review, 32 (4), 1180-1198. (DOI: 10.5465/amr.2007.26586092).

Goguen, J. A. (1969), "The logic of inexact concepts," Synthese, 19 (3-4), 325-373. (DOI: 10.1007/BF00485654).

Greckhamer, Thomas (2011), "Cross-cultural differences in compensation level and inequality across occupations: A set-theoretic analysis," Organization Studies, 32 (1), 85-115. (DOI: 10.1177/0170840610380806). 
López-Duarte, Cristina, Marta M. Vidal-Suárez, and Belén González-Díaz (2015), "Impact of cultural positions on fdi's entry mode," Cross Cultural Management: An International Journal, 22 (3), 509-526. (DOI: doi:10.1108/CCM-07-2014-0086).

Marchi, Gianluca, Marina Vignola, Gisella Facchinetti, and Giovanni Mastroleo (2014), "International market selection for small firms: A fuzzy-based decision process," European Journal of Marketing, 48 (11-12), 2198-2212. (DOI: 10.1108/ejm-09-20120512).

Ragin, Charles C. (1987), The comparative method: Moving beyond qualitative and quantitative strategies Berkeley, Los Angeles and London: University of California Press.

Ragin, Charles C. (1994), Constructing social research: The unity and diversity of method. Thousand Oaks, London and New Delhi 1994: Pine Forge Press.

Ragin, Charles C. (2000), Fuzzy-set social science. Chicago, IL: Chicago University Press.

Ragin, Charles C. (2008a), Redesigning social inquiry: Fuzzy sets and beyond. Chicago: University of Chicago Press.

Ragin, Charles C. (2008b), User's guide to fuzzy-set/qualitative comparative analysis. Tucson, AZ: University of Arizona.

Ragin, Charles C. (2014), The comparative method moving beyond qualitative and quantitative strategies. Berkeley: University of California Press.

Ragin, Charles C. and Lisa M. Amoroso (2011), Constructing social research: The unity and diversity of method. Los Angeles: Sage Publications.

Ragin, Charles C. and Howard Saul Becker (1992), What is a case?: Exploring the foundations of social inquiry. Cambridge [England]: Cambridge University Press.

Rihoux, Benoît (2006), "Qualitative comparative analysis (qca) and related systematic comparative methods: Recent advances and remaining challenges for social science research," International Sociology, 21 (5), 679-706. (DOI: 10.1177/0268580906067836).

Rihoux, Benoît and Charles C. Ragin (2009), Configurational comparative methods: Qualitative comparative analysis (qca) and related techniques. Thousand Oaks: Sage.

Roig-Tierno, Norat, Kun-Huang Huarng, and Domingo Ribeiro-Soriano (2016), "Qualitative comparative analysis: Crisp and fuzzy sets in business and management," Journal of Business Research, 69 (4), 1261-1264. (DOI: 10.1016/j.jbusres.2015.10.089).

Seny Kan, Anderson Konan, Emmanuel Adegbite, Sami El Omari, and Mahamat Abdellatif (2016), "On the use of qualitative comparative analysis in management," Journal of Business Research, 69 (4), 1458-1463. (DOI: 10.1016/j.jbusres.2015.10.125).

Sinkovics, Rudolf R. and Eva Alfoldi (2012), "Progressive focusing and trustworthiness in qualitative research," Management International Review, 52 (6), 817-845. (DOI: 10.1007/s11575-012-0140-5).

Stokke, Olav Schram (2007), "Qualitative comparative analysis, shaming, and international regime effectiveness," Journal of Business Research, 60 (5), 501-511. (DOI: 10.1016/j.jbusres.2007.01.003).

Zadeh, Lotfi A. (1965), "Fuzzy sets," Information and control, 8 (3), 338-353.

Zimmermann, H. J. (2010), "Fuzzy set theory," Wiley Interdisciplinary Reviews: Computational Statistics, 2 (3), 317-332. (DOI: 10.1002/wics.82). 


\section{Appendix - Tables and figures}

Figure 1: The use of fsQCA in management research (Seny Kan et al. 2016)
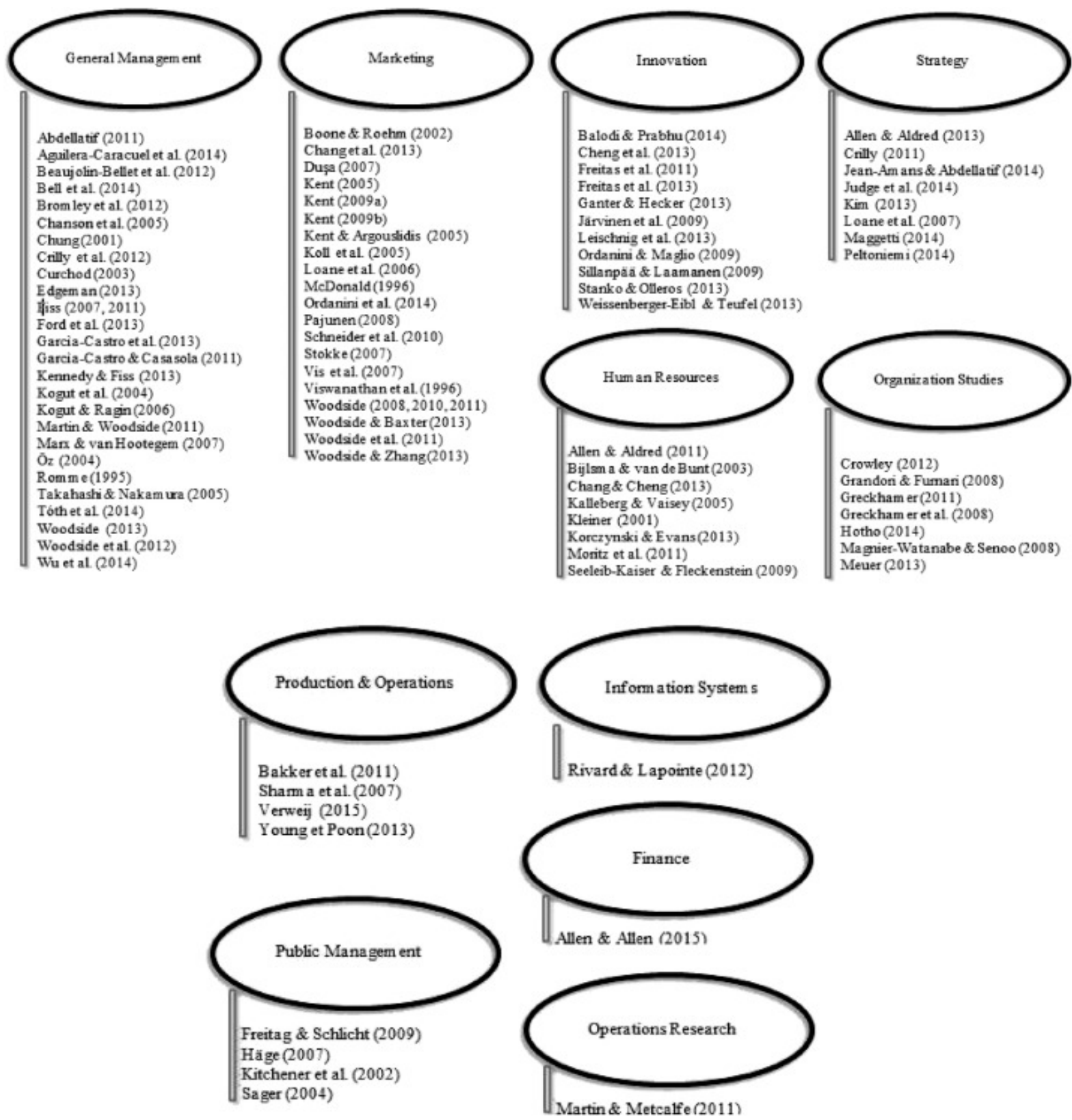

Table 1: Recent business papers using fsQCA (organisational, entrepreneurial and firm performance topics)

\begin{tabular}{|l|l|l|l|l|}
\hline Business paper & Journal & Topic & Approach & \multicolumn{1}{|l|}{$\begin{array}{l}\text { Level of } \\
\text { analysis }\end{array}$} \\
\hline $\begin{array}{l}\text { Coduras, Clemente } \\
\text { and Ruiz (2016) }\end{array}$ & $\begin{array}{l}\text { Journal } \\
\text { of } \\
\text { Business }\end{array}$ & Global Entrepreneurship & $\begin{array}{l}\text { Entrepreneurial } \\
\text { attitudes } \\
\text { and social values }\end{array}$ & $\begin{array}{l}\text { Global } \\
\text { Entrepreneurs } \\
\text { hip }\end{array}$ \\
\hline
\end{tabular}




\begin{tabular}{|c|c|c|c|c|}
\hline & Research & & $\begin{array}{l}\text { of adult } \\
\text { populations toward } \\
\text { entrepreneurship. }\end{array}$ & Monitor data. \\
\hline $\begin{array}{l}\text { Beynon, Jones and } \\
\text { Pickernell (2016) }\end{array}$ & $\begin{array}{l}\text { Journal } \\
\text { of } \\
\text { Business } \\
\text { Research }\end{array}$ & Enterpreneurship & $\begin{array}{l}\text { Relationship } \\
\text { between } \\
\text { entrepreneurial } \\
\text { attitudes } \\
\text { and activity. }\end{array}$ & $\begin{array}{l}\text { cross-country } \\
\text { comparison }\end{array}$ \\
\hline $\begin{array}{l}\text { Chaparro-Peláez, } \\
\text { Agudo-Peregrina } \\
\text { and } \\
\text { Pascual-Miguel } \\
(2016)\end{array}$ & $\begin{array}{l}\text { Journal } \\
\text { of } \\
\text { Business } \\
\text { Research }\end{array}$ & $\begin{array}{l}\text { Drivers and inhibitors } \\
\text { of e-commerce adoption. } \\
\text { from a }\end{array}$ & $\begin{array}{l}\text { Electronic } \\
\text { commerce } \\
\text { behavior }\end{array}$ & \\
\hline $\begin{array}{l}\text { Jenson, Leith, } \\
\text { Doyle, West, and } \\
\text { Miles (2016) }\end{array}$ & $\begin{array}{l}\text { Journal } \\
\text { of } \\
\text { Business } \\
\text { Research }\end{array}$ & innovation system failure & $\begin{array}{l}\text { innovation systems } \\
\text { theory }\end{array}$ & $\begin{array}{l}\text { multiple case } \\
\text { study }\end{array}$ \\
\hline $\begin{array}{l}\text { Kuckertz, Berger, } \\
\text { andMpeqa (2016) }\end{array}$ & $\begin{array}{l}\text { Journal } \\
\text { of } \\
\text { Business } \\
\text { Research }\end{array}$ & $\begin{array}{l}\text { entrepreneurial } \\
\text { activity in the application } \\
\text { to }\end{array}$ & $\begin{array}{l}\text { factor-driven, } \\
\text { efficiency-driven, } \\
\text { and innovation- } \\
\text { driven economies }\end{array}$ & \\
\hline $\begin{array}{l}\text { Domenech, } \\
\text { Escamilla, and } \\
\text { Roig-Tierno (2016) }\end{array}$ & $\begin{array}{l}\text { Journal } \\
\text { of } \\
\text { Business } \\
\text { Research }\end{array}$ & $\begin{array}{l}\text { Knowledge-intensive } \\
\text { activities from a regional }\end{array}$ & $\begin{array}{l}\text { causal model to } \\
\text { explain how these } \\
\text { factors affect } \\
\text { knowledge- } \\
\text { intensive } \\
\text { activities }\end{array}$ & \\
\hline $\begin{array}{l}\text { Leischnig and } \\
\text { Kasper-B rauer } \\
(2016)\end{array}$ & $\begin{array}{l}\text { Journal } \\
\text { of } \\
\text { Business } \\
\text { Research }\end{array}$ & Firm profitability & Selling & $\begin{array}{l}\text { a two-level } \\
\text { approach to } \\
\text { industry } \\
\text { factors and } \\
\text { selling factors }\end{array}$ \\
\hline $\begin{array}{l}\text { Muñoz and Kibler } \\
\text { (2016) }\end{array}$ & $\begin{array}{l}\text { Journal } \\
\text { of } \\
\text { Business } \\
\text { Research }\end{array}$ & $\begin{array}{l}\text { Social } \\
\text { entrepreneurship. } \\
\text { institutional complexity } \\
\text { of social entrepreneurship } \\
\text { and explain under which }\end{array}$ & $\begin{array}{l}\text { Institutional } \\
\text { Theory }\end{array}$ & $\begin{array}{l}\text { combinations } \\
\text { of } \\
\text { local } \\
\text { institutional } \\
\text { forces social } \\
\text { entrepreneurs } \\
\text { build } \\
\text { opportunity } \\
\text { confidence. }\end{array}$ \\
\hline $\begin{array}{l}\text { Lisboa, Skarmeas, } \\
\text { and Saridakis } \\
(2016)\end{array}$ & $\begin{array}{l}\text { Journal } \\
\text { of } \\
\text { Business } \\
\text { Research }\end{array}$ & Entrepreneurship & $\begin{array}{l}\text { entrepreneurial } \\
\text { orientation towards } \\
\text { firm performance }\end{array}$ & $\begin{array}{l}\text { causal } \\
\text { mechanisms } \\
\text { by which } \\
\text { those factors } \\
\text { collectively } \\
\text { affect } \\
\text { performance. }\end{array}$ \\
\hline $\begin{array}{l}\text { Ospina Delgado and } \\
\text { Zorio Grima (2016) }\end{array}$ & $\begin{array}{l}\text { Journal } \\
\text { of } \\
\text { Business } \\
\text { Research }\end{array}$ & innovation at universities. & $\begin{array}{l}\text { complex cause- } \\
\text { effect relationship } \\
\text { between innovation } \\
\text { and the } \\
\text { supply of } \\
\text { university courses }\end{array}$ & \\
\hline $\begin{array}{l}\text { Wang, Yu, and } \\
\text { Chiang (2016) }\end{array}$ & $\begin{array}{l}\text { Journal } \\
\text { of } \\
\text { Business } \\
\text { Research }\end{array}$ & $\begin{array}{l}\text { Value relevance } \\
\text { of corporate reputation }\end{array}$ & $\begin{array}{l}\text { Corporate } \\
\text { reputation }\end{array}$ & Taiwan \\
\hline Wang, Yu, and & Journal & Manager's & Export decisions. & corporate \\
\hline
\end{tabular}




\begin{tabular}{|c|c|c|c|c|}
\hline Chiang (2016) & $\begin{array}{l}\text { of } \\
\text { Business } \\
\text { Research } \\
\end{array}$ & $\begin{array}{l}\text { educational background } \\
\text { and ICT }\end{array}$ & & \\
\hline $\begin{array}{l}\text { Benavides Espinosa } \\
\text { and Merigo Lindahl } \\
(2016)\end{array}$ & $\begin{array}{l}\text { Journal } \\
\text { of } \\
\text { Business } \\
\text { Research }\end{array}$ & $\begin{array}{l}\text { Organizational } \\
\text { design as a learning } \\
\text { enabler }\end{array}$ & $\begin{array}{l}\text { different design } \\
\text { variables and their } \\
\text { effect on } \\
\text { organizational } \\
\text { learning. }\end{array}$ & \\
\hline Wu (2016) & $\begin{array}{l}\text { Journal } \\
\text { of } \\
\text { Business } \\
\text { Research }\end{array}$ & $\begin{array}{l}\text { International marketing } \\
\text { strategy modeling of } \\
\text { leisure } \\
\text { farm. }\end{array}$ & $\begin{array}{l}\text { international } \\
\text { marketing } \\
\text { strategies, and } \\
\text { performance }\end{array}$ & $\begin{array}{l}\text { leisure farm } \\
\text { context. }\end{array}$ \\
\hline $\begin{array}{l}\text { Simón-Moya and } \\
\text { Revuelto-Taboada } \\
(2016)\end{array}$ & $\begin{array}{l}\text { Journal } \\
\text { of } \\
\text { Business } \\
\text { Research }\end{array}$ & $\begin{array}{l}\text { Revising the predictive } \\
\text { capability of business plan } \\
\text { quality for new firm } \\
\text { survival }\end{array}$ & $\begin{array}{l}\text { between business } \\
\text { plan quality and } \\
\text { survival rates of } \\
\text { new ventures }\end{array}$ & \\
\hline $\begin{array}{l}\text { Cobo-Benita, } \\
\text { Rodríguez-Segura, } \\
\text { Ortiz- } \\
\text { Marcos, and } \\
\text { Ballesteros-Sánchez } \\
(2016)\end{array}$ & $\begin{array}{l}\text { Journal } \\
\text { of } \\
\text { Business } \\
\text { Research }\end{array}$ & $\begin{array}{l}\text { Innovation projects } \\
\text { performance }\end{array}$ & $\begin{array}{l}\text { organizational } \\
\text { theory }\end{array}$ & $\begin{array}{l}\text { large sample } \\
\text { of firms in } \\
\text { Spain } \\
\text { appearing in } \\
\text { the } \\
\text { Community } \\
\text { Innovation } \\
\text { survey }\end{array}$ \\
\hline $\begin{array}{l}\text { Bergmann, } \\
\text { Stechemeser, and } \\
\text { Guenther (2016) }\end{array}$ & $\begin{array}{l}\text { Journal } \\
\text { of } \\
\text { Business } \\
\text { Research }\end{array}$ & $\begin{array}{l}\text { Financial performance and } \\
\text { natural resource } \\
\text { dependence theory. }\end{array}$ & $\begin{array}{l}\text { natural resource } \\
\text { dependence } \\
\text { theory }\end{array}$ & \\
\hline $\begin{array}{l}\text { Lassala, Carmona, } \\
\text { and Momparler } \\
(2016)\end{array}$ & $\begin{array}{l}\text { Journal } \\
\text { of } \\
\text { Business } \\
\text { Research }\end{array}$ & $\begin{array}{l}\text { Alternative paths to high } \\
\text { consulting fees }\end{array}$ & $\begin{array}{l}\text { customer } \\
\text { satisfaction }\end{array}$ & \\
\hline $\begin{array}{l}\text { Felício, } \\
\text { Duarte, and } \\
\text { Rodrigues (2016) }\end{array}$ & $\begin{array}{l}\text { Journal } \\
\text { of } \\
\text { Business } \\
\text { Research }\end{array}$ & $\begin{array}{l}\text { Global mindset to SME } \\
\text { internationalization. }\end{array}$ & $\begin{array}{l}\text { SMEs' } \\
\text { internationalization } \\
\text { behavior }\end{array}$ & $\begin{array}{l}\text { relationship } \\
\text { between } \\
\text { IGM and } \\
\text { CGM. }\end{array}$ \\
\hline $\begin{array}{l}\text { Adame, Caplliure, } \\
\text { and Miquel (2016) }\end{array}$ & $\begin{array}{l}\text { Journal } \\
\text { of } \\
\text { Business } \\
\text { Research } \\
\end{array}$ & $\begin{array}{l}\text { women's presence in the } \\
\text { workplace }\end{array}$ & $\begin{array}{l}\text { work-life balance } \\
\text { policies }\end{array}$ & \\
\hline $\begin{array}{l}\text { Urueña and Hidalgo } \\
\text { (2016) }\end{array}$ & $\begin{array}{l}\text { Journal } \\
\text { of } \\
\text { Business } \\
\text { Research }\end{array}$ & loyalty in e-complaints. & customer loyalty. & $\begin{array}{l}\text { a sample of e- } \\
\text { commerce } \\
\text { users who file } \\
\text { complaints } \\
\text { after } \\
\text { shopping } \\
\text { online, }\end{array}$ \\
\hline $\begin{array}{l}\text { Alegre, Mas- } \\
\text { Machuca, and } \\
\text { Berbegal-Mirabent } \\
(\mathbf{2 0 1 6})\end{array}$ & $\begin{array}{l}\text { Journal } \\
\text { of } \\
\text { Business } \\
\text { Research }\end{array}$ & Employee job satisfaction. & $\begin{array}{l}\text { (1) teamwork, (2) } \\
\text { employeework- } \\
\text { family balance, and } \\
\text { (3) supervisor } \\
\text { support and } \\
\text { identification } \\
\text { with the strategy. }\end{array}$ & \\
\hline $\begin{array}{l}\text { Whittington } \\
\text { and Bell (2016) }\end{array}$ & $\begin{array}{l}\text { Journal } \\
\text { of } \\
\text { Business } \\
\text { Research }\end{array}$ & $\begin{array}{l}\text { Employee performance, } \\
\text { commitment and } \\
\text { citizenship behaviors. }\end{array}$ & $\begin{array}{l}\text { Leadership and } \\
\text { motivational } \\
\text { constructs }\end{array}$ & \\
\hline Pinazo-Dallenbach, & Journal & Enterpreneurship & Entrepreneurial & high-potential \\
\hline
\end{tabular}




\begin{tabular}{|c|c|c|c|c|}
\hline $\begin{array}{l}\text { Mas-Tur, and } \\
\text { Lloria (2016) }\end{array}$ & $\begin{array}{l}\text { of } \\
\text { Business } \\
\text { Research }\end{array}$ & & $\begin{array}{l}\text { characteristics (i.e. } \\
\text { education, } \\
\text { gender,motivation, } \\
\text { and age) and } \\
\text { environmental } \\
\text { variables (i.e. } \\
\text { citizen insecurity) }\end{array}$ & firms \\
\hline $\begin{array}{l}\text { Comeig, Grau- } \\
\text { Grau, } \\
\text { Jaramillo- } \\
\text { Gutiérrez, and } \\
\text { Ramírez (2016) }\end{array}$ & $\begin{array}{l}\text { Journal } \\
\text { of } \\
\text { Business } \\
\text { Research }\end{array}$ & $\begin{array}{l}\text { Relationship } \\
\text { with competition } \\
\text { preferences and the } \\
\text { different paths that may } \\
\text { lead } \\
\text { to enter competition. }\end{array}$ & Entry Strategy & \\
\hline $\begin{array}{l}\text { Bigné, Llinares, } \\
\text { and Torrecilla } \\
(2016)\end{array}$ & $\begin{array}{l}\text { Journal } \\
\text { of } \\
\text { Business } \\
\text { Research }\end{array}$ & $\begin{array}{l}\text { Consumer choice, } \\
\text { customer experience, and } \\
\text { shopping behavior } \\
\text { in a store - virtual reality }\end{array}$ & $\begin{array}{l}\text { Customer } \\
\text { behaviour, } \\
\text { Neuroscience }\end{array}$ & $\begin{array}{l}\text { virtual } \\
\text { reality-based } \\
\text { study }\end{array}$ \\
\hline $\begin{array}{l}\text { Fiss, Frambach, and } \\
\text { Ingenbleek }\end{array}$ & $\begin{array}{l}\text { Journal } \\
\text { of } \\
\text { Business } \\
\text { Research }\end{array}$ & $\begin{array}{l}\text { Customer orientation and } \\
\text { superior firm performance }\end{array}$ & $\begin{array}{l}\text { Configurational, } \\
\text { strategic } \\
\text { orientations, } \\
\text { strategy types, and } \\
\text { market conditions }\end{array}$ & \\
\hline $\begin{array}{l}\text { Kulins, Leonardy, } \\
\text { and Weber (2016) }\end{array}$ & $\begin{array}{l}\text { Journal } \\
\text { of } \\
\text { Business } \\
\text { Research }\end{array}$ & $\begin{array}{l}\text { Relationship between } \\
\text { business model, design, } \\
\text { and financial performance. }\end{array}$ & Configurational & \\
\hline $\begin{array}{l}\text { Romero, Lafont, } \\
\text { Tafur, and Eguren } \\
(\mathbf{2 0 1 6 )}\end{array}$ & $\begin{array}{l}\text { Journal } \\
\text { of } \\
\text { Business } \\
\text { Research }\end{array}$ & $\begin{array}{l}\text { Performance and value } \\
\text { creation at } \\
\text { United Kingdom's airports } \\
\text {. }\end{array}$ & $\begin{array}{l}\text { Governance, } \\
\text { revenue structure, } \\
\text { airlines, } \\
\text { passengers, and } \\
\text { strategy }\end{array}$ & \\
\hline $\begin{array}{l}\text { Berbegal-Mirabent } \\
\text { and Llopis-Albert }\end{array}$ & $\begin{array}{l}\text { Journal } \\
\text { of } \\
\text { Business } \\
\text { Research }\end{array}$ & $\begin{array}{l}\text { Driving forces in } \\
\text { collaborative } \\
\text { research contracts } \\
\text { of science-industry R\&D } \\
\text { partnerships. }\end{array}$ & $\begin{array}{l}\text { human capital } \\
\text { experience, the } \\
\text { profile, and the } \\
\text { capacity attraction } \\
\text { affect the } \\
\text { performance }\end{array}$ & \\
\hline $\begin{array}{l}\text { González-Cruz and } \\
\text { Cruz-Ros }(2016)\end{array}$ & $\begin{array}{l}\text { Journal } \\
\text { of } \\
\text { Business } \\
\text { Research }\end{array}$ & $\begin{array}{l}\text { Family involvement } \\
\text { produce superior } \\
\text { performance in SME } \\
\text { family business }\end{array}$ & $\begin{array}{l}\text { SME family } \\
\text { businesses. }\end{array}$ & \\
\hline $\begin{array}{l}\text { Seny Kan, Adegbite, } \\
\text { El Omari, and } \\
\text { Abdellatif (2016) }\end{array}$ & $\begin{array}{l}\text { Journal } \\
\text { of } \\
\text { Business } \\
\text { Research }\end{array}$ & $\begin{array}{l}\text { Comprehensive review of } \\
\text { the uses of QCA in the } \\
\text { field of management } \\
\text { research. }\end{array}$ & $\begin{array}{l}\text { Organizing the } \\
\text { field, the study } \\
\text { identifies } \\
\text { current } \\
\text { management issues } \\
\text { of interest. }\end{array}$ & \\
\hline $\begin{array}{l}\text { Nair and Gibbert } \\
(2016)\end{array}$ & $\begin{array}{l}\text { Journal } \\
\text { of } \\
\text { Business } \\
\text { Research }\end{array}$ & $\begin{array}{l}\text { Analyzing inconsistent } \\
\text { cases in management } \\
\text { fsQCA studies }\end{array}$ & $\begin{array}{l}\text { Theory-building of } \\
\text { deviant cases }\end{array}$ & \\
\hline $\begin{array}{l}\text { Ferreira, Jalali, and } \\
\text { Ferreira (2016) }\end{array}$ & $\begin{array}{l}\text { Journal } \\
\text { of } \\
\text { Business } \\
\text { Research }\end{array}$ & $\begin{array}{l}\text { Fuzzy cognitive maps } \\
\text { (FCMs) serve as support in } \\
\text { the selection of } \\
\text { independent variables }\end{array}$ & $\begin{array}{l}\text { specific FCM to } \\
\text { integrate in the } \\
\text { QCA } \\
\text { guidelines. }\end{array}$ & \\
\hline $\begin{array}{l}\text { Fotiadis, Yeh, and } \\
\text { Huan (2016) }\end{array}$ & $\begin{array}{l}\text { Journal } \\
\text { of } \\
\text { Business }\end{array}$ & $\begin{array}{l}\text { Rural tourism } \\
\text { success recipes }\end{array}$ & $\begin{array}{l}\text { Configurational } \\
\text { analysis, } \\
\text { collaborational }\end{array}$ & \\
\hline
\end{tabular}




\begin{tabular}{|c|c|c|c|c|}
\hline & Research & & skills & \\
\hline $\begin{array}{l}\text { Gonçalves, } \\
\text { Lourenço, and Silva } \\
(2016)\end{array}$ & $\begin{array}{l}\text { Journal } \\
\text { of } \\
\text { Business } \\
\text { Research }\end{array}$ & $\begin{array}{l}\text { Consumption values } \\
\text { predict green buying } \\
\text { behavior. } \\
\text {. }\end{array}$ & $\begin{array}{l}\text { Emotional, } \\
\text { conditional, and } \\
\text { social values to } \\
\text { predict the buying } \\
\text { green behavior }\end{array}$ & \\
\hline $\begin{array}{l}\text { Hernández-García, } \\
\text { Iglesias-Prada, and } \\
\text { Fernández- } \\
\text { Cardador }(\mathbf{2 0 1 6})\end{array}$ & $\begin{array}{l}\text { Journal } \\
\text { of } \\
\text { Business } \\
\text { Research }\end{array}$ & $\begin{array}{l}\text { Causal recipes for } \\
\text { acceptance and refusal of } \\
\text { corporate } \\
\text { blogs }\end{array}$ & $\begin{array}{l}\text { Sharing knowledge } \\
\text { in the organization }\end{array}$ & \\
\hline $\begin{array}{l}\text { Hernández-Perlines, } \\
\text { Moreno- } \\
\text { Garcia, and Yáñez- } \\
\text { Araque (2016) }\end{array}$ & $\begin{array}{l}\text { Journal } \\
\text { of } \\
\text { Business } \\
\text { Research }\end{array}$ & $\begin{array}{l}\text { Absorption capacity in the } \\
\text { training } \\
\text { process that can increase } \\
\text { the performance of } \\
\text { organizations. }\end{array}$ & $\begin{array}{l}\text { Absorptive } \\
\text { capacity }\end{array}$ & \\
\hline $\begin{array}{l}\text { Pu Hai, Roig-Dobón } \\
\text { and Sánchez-García } \\
(2016)\end{array}$ & $\begin{array}{l}\text { Journal } \\
\text { of } \\
\text { Business } \\
\text { Research }\end{array}$ & $\begin{array}{l}\text { Public policy } \\
\text { for innovative governance. }\end{array}$ & Innovation & \\
\hline $\begin{array}{l}\text { Jacobs, Cambré, } \\
\text { Huysentruyt, and } \\
\text { Schramme (2016) }\end{array}$ & $\begin{array}{l}\text { Journal } \\
\text { of } \\
\text { Business } \\
\text { Research }\end{array}$ & $\begin{array}{l}\text { Success in the fashion } \\
\text { Industry and dominant } \\
\text { logic, organizational life } \\
\text { cycle, }\end{array}$ & $\begin{array}{l}\text { Concepts of } \\
\text { organizational life } \\
\text { cycle }\end{array}$ & \\
\hline $\begin{array}{l}\text { Ott and Kimura } \\
(2016)\end{array}$ & $\begin{array}{l}\text { Journal } \\
\text { of } \\
\text { Business } \\
\text { Research }\end{array}$ & $\begin{array}{l}\text { Negotiations in Japanese } \\
\text { Multinational Enterprises }\end{array}$ & Bargaining theory & Firm-level \\
\hline Fan et al. (2016) & $\begin{array}{l}\text { Internati } \\
\text { onal } \\
\text { Business } \\
\text { Review }\end{array}$ & $\begin{array}{l}\text { The factors that influence } \\
\text { localised learning by } \\
\text { Chinese multinationals } \\
\text { who have made FDI in } \\
\text { Australia }\end{array}$ & Dynamic capability & Firm-level \\
\hline $\begin{array}{l}\text { López-Duarte, } \\
\text { Vidal-Suárez, and } \\
\text { González-Díaz } \\
\text { (2015) }\end{array}$ & $\begin{array}{l}\text { Cross } \\
\text { Cultural } \\
\text { Manage } \\
\text { ment }\end{array}$ & $\begin{array}{l}\text { Study the influence of } \\
\text { cultural positions on the } \\
\text { choice of } \\
\text { entry mode in foreign } \\
\text { direct investment (FDI) }\end{array}$ & $\begin{array}{l}\text { Cultural Distance } \\
\text { Paradox }\end{array}$ & Country-level \\
\hline Marchi et al. (2014) & $\begin{array}{l}\text { Europea } \\
\mathrm{n} \text { Journal } \\
\text { of } \\
\text { Marketin } \\
\mathrm{g}\end{array}$ & $\begin{array}{l}\text { Examining the factors that } \\
\text { influence the international } \\
\text { market decision making } \\
\text { process of small firms }\end{array}$ & $\begin{array}{l}\text { Behaviour-based } \\
\text { international } \\
\text { market decision } \\
\text { making process }\end{array}$ & $\begin{array}{l}\text { Country-level } \\
\text { and Firm- } \\
\text { level }\end{array}$ \\
\hline Greckhamer (2011) & $\begin{array}{l}\text { Organiza } \\
\text { tional } \\
\text { Studies }\end{array}$ & $\begin{array}{l}\text { Investigates whether } \\
\text { combinations of cultural } \\
\text { and macro-environmental } \\
\text { attributes are associated } \\
\text { with differences in } \\
\text { compensation level and } \\
\text { compensation inequality in } \\
\text { different countries }\end{array}$ & $\begin{array}{l}\text { Compensation and } \\
\text { culture }\end{array}$ & Country-level \\
\hline Crilly (2011) & $\begin{array}{l}\text { Journal } \\
\text { of } \\
\text { Internati } \\
\text { onal } \\
\text { Business } \\
\text { Studies }\end{array}$ & $\begin{array}{l}\text { Investigates the conditions } \\
\text { under which overseas } \\
\text { subsidiaries accept a } \\
\text { shareholder-centric } \\
\text { approach as against a } \\
\text { stakeholder-centric } \\
\text { approach to management }\end{array}$ & $\begin{array}{l}\text { Stakeholder } \\
\text { orientation }\end{array}$ & Firm-level \\
\hline Fiss (2011) & AMJ & $\begin{array}{l}\text { Organizational Theory and } \\
\text { configurations }\end{array}$ & $\begin{array}{l}\text { Organization } \\
\text { Theory }\end{array}$ & \\
\hline
\end{tabular}




\begin{tabular}{|l|l|l|l|l|}
\hline Kvist (2007) & JBR & $\begin{array}{l}\text { Configurational Approach } \\
\text { in Business Research }\end{array}$ & $\begin{array}{l}\text { Organization } \\
\text { Theory }\end{array}$ & \\
\hline
\end{tabular}

\section{Figure 2: FsQCA Data sheet after Calibration in csv}

\begin{tabular}{|c|c|c|c|c|c|c|c|c|}
\hline \multicolumn{6}{|c|}{ 7/F5/QCA Data Sheet } & & \multicolumn{2}{|c|}{ - $|\square| x \mid$} \\
\hline File & Vari & Case & Analyze & Giraphs & & & & \\
\hline & Case & name & gdpf & ingf & manf & unf & weakcv & 드 \\
\hline & 1 & AUS & 0.9 & 0.7 & 0.3 & 0.7 & 0.7 & \\
\hline & 2 & BEL & 0.7 & 0.1 & 0.1 & 0.9 & 0.7 & \\
\hline & 3 & DEN & 0.7 & 0.3 & 0.1 & 0.9 & 0.1 & \\
\hline & 4 & FRA & 0.7 & 0.9 & 0.1 & 0.1 & 0.9 & \\
\hline & 5 & GER & 0.7 & 0.9 & 0.3 & 0.3 & 0.7 & \\
\hline & 6 & IRE & 0.1 & 0.7 & 0.9 & 0.7 & 0.9 & \\
\hline & 7 & ITA & 0.3 & 0.9 & 0.1 & 0.7 & 0.7 & \\
\hline & 8 & NET & 0.7 & 0.3 & 0.1 & 0.3 & 0.9 & \\
\hline & 9 & NOR & 0.7 & 0.3 & 0.7 & 0.9 & 0.1 & \\
\hline & 10 & SWE & 0.9 & 0.3 & 0.9 & 1 & 0 & \\
\hline & 11 & UKN & 0.7 & 0.7 & 0.9 & 0.7 & 0.3 & \\
\hline & 12 & USA & 1 & 0.9 & 0.3 & 0.1 & 1 & -1 \\
\hline 1 & & & & & & & 1 & \\
\hline
\end{tabular}

File: CV1379.CSV

\section{Figure 3: Selection of conditions}

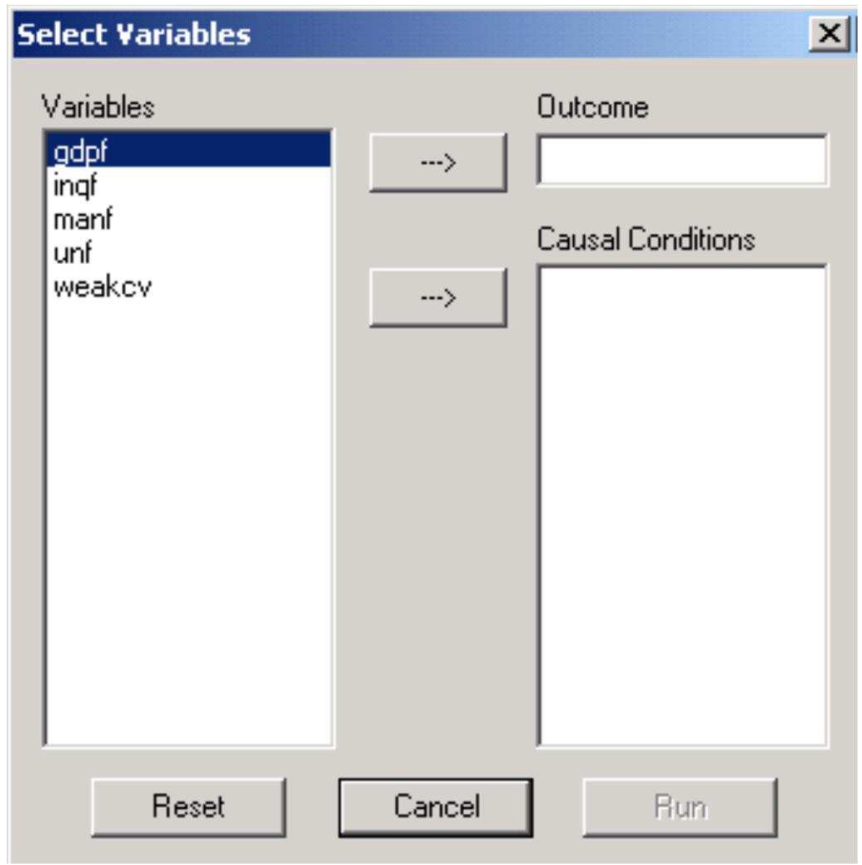


Figure 4: Truth table

\begin{tabular}{|c|c|c|c|c|c|c|c|c|c|}
\hline \multicolumn{4}{|c|}{ 12. Edit Truth Table } & & & & & E回 & $\sqrt{x}$ \\
\hline \multicolumn{10}{|c|}{ File Edit Sort } \\
\hline gdpf & ingf & manf & unf & number. & weakcr & consist & pre & product & A \\
\hline 1 & 1 & 0 & 0 & $3 \quad(25 \%)$ & & 0.950000 & 0.909091 & 0.863636 & \\
\hline 1 & 0 & 0 & 1 & $2 \quad(41 \%)$ & & 0.736842 & 0.523810 & 0.385965 & \\
\hline 1 & 0 & 1 & 1 & $2 \quad(58 \%)$ & & 0.666667 & 0.333333 & 0.222222 & \\
\hline 0 & 1. & 0 & 1 & $1 \quad(66 \%)$ & & 0.764706 & 0.529412 & 0.404844 & \\
\hline 0 & 1 & 1 & 1 & $1 \quad(75 \%)$ & & 0.812500 & 0.571429 & 0.464286 & \\
\hline 1 & 0 & 0 & 0 & $1 \quad(83 \%)$ & & 0.928571 & 0.833333 & 0.773809 & \\
\hline 1 & 1 & 0. & 1 & $1 \quad(91 \%)$ & & 0.789474 & 0.600000 & 0.473684 & \\
\hline 1 & 1 & 1 & 1 & $1 \quad(100 \%)$ & & 0.722222 & 0.411765 & 0.297386 & \\
\hline 0 & 0 & 0 & 0 & $0 \quad(100 \%)$ & & 0.909091 & 0.714286 & 0.649351 & \\
\hline 0 & 0 & 0 & 1 & $0 \quad(100 \%)$ & & 0.733333 & 0.428571 & 0.314286 & \\
\hline 0 & 0 & 1 & 0 & $0 \quad(100 \%)$ & & 0.916667 & 0.714286 & 0.654762 & \\
\hline 0 & 0 & 1 & 1 & $0 \quad(100 \%)$ & & 0.785714 & 0.454546 & 0.357143 & \\
\hline n & 1 & n & n & ก $(1 \cap n \%)$ & & ก. 978571 & ก.R1818? & ก. $75974 n$ & $\underline{v}$ \\
\hline \multirow[t]{2}{*}{$\leq$} & & & & - & & & & 2 & \\
\hline & & \multicolumn{2}{|c|}{ Specily Analysis } & Cancel & \multicolumn{2}{|c|}{ Standard Analyses } & & & \\
\hline
\end{tabular}

Figure 5: Truth table

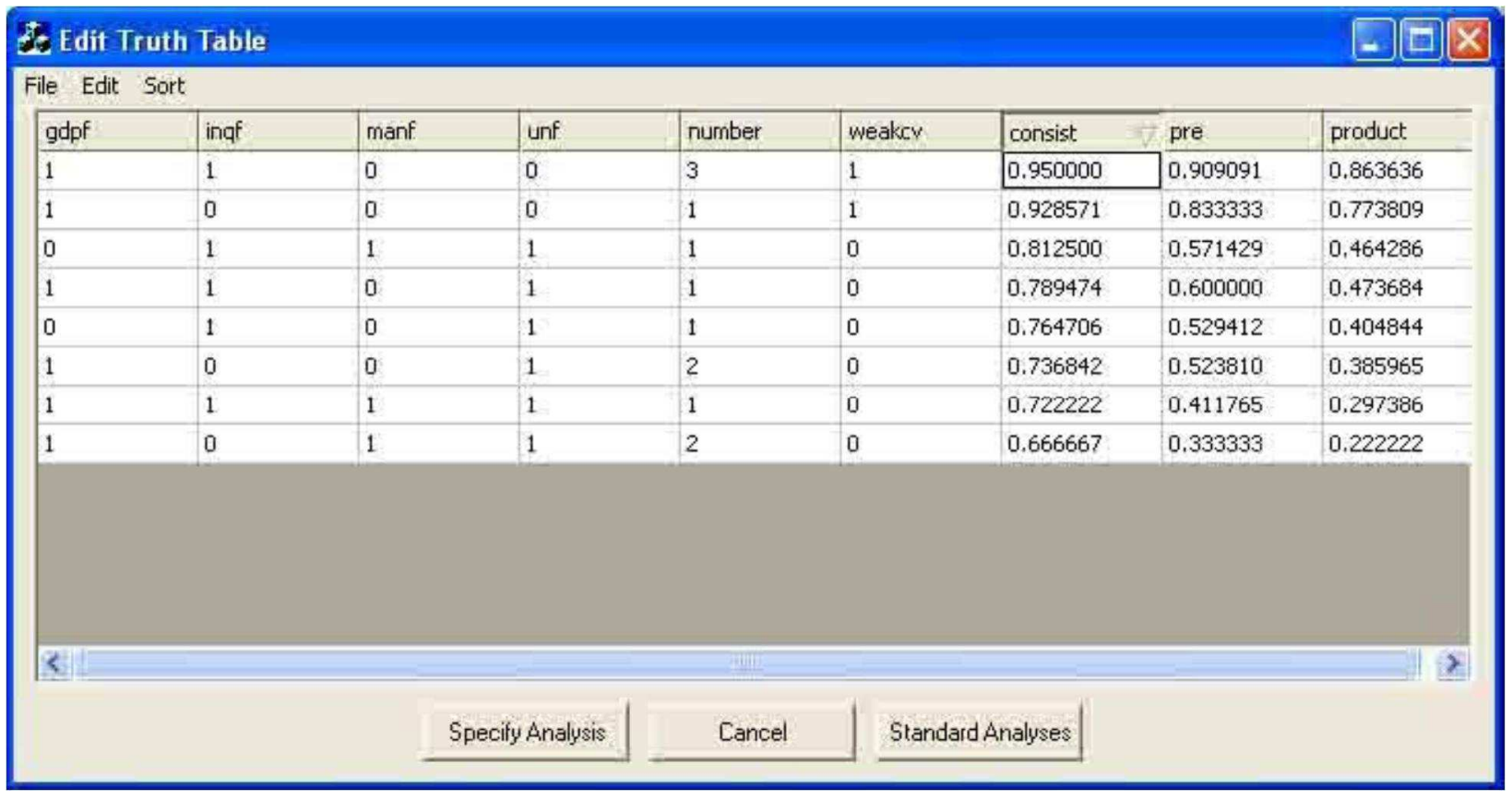


Figure 6: Truth table analysis

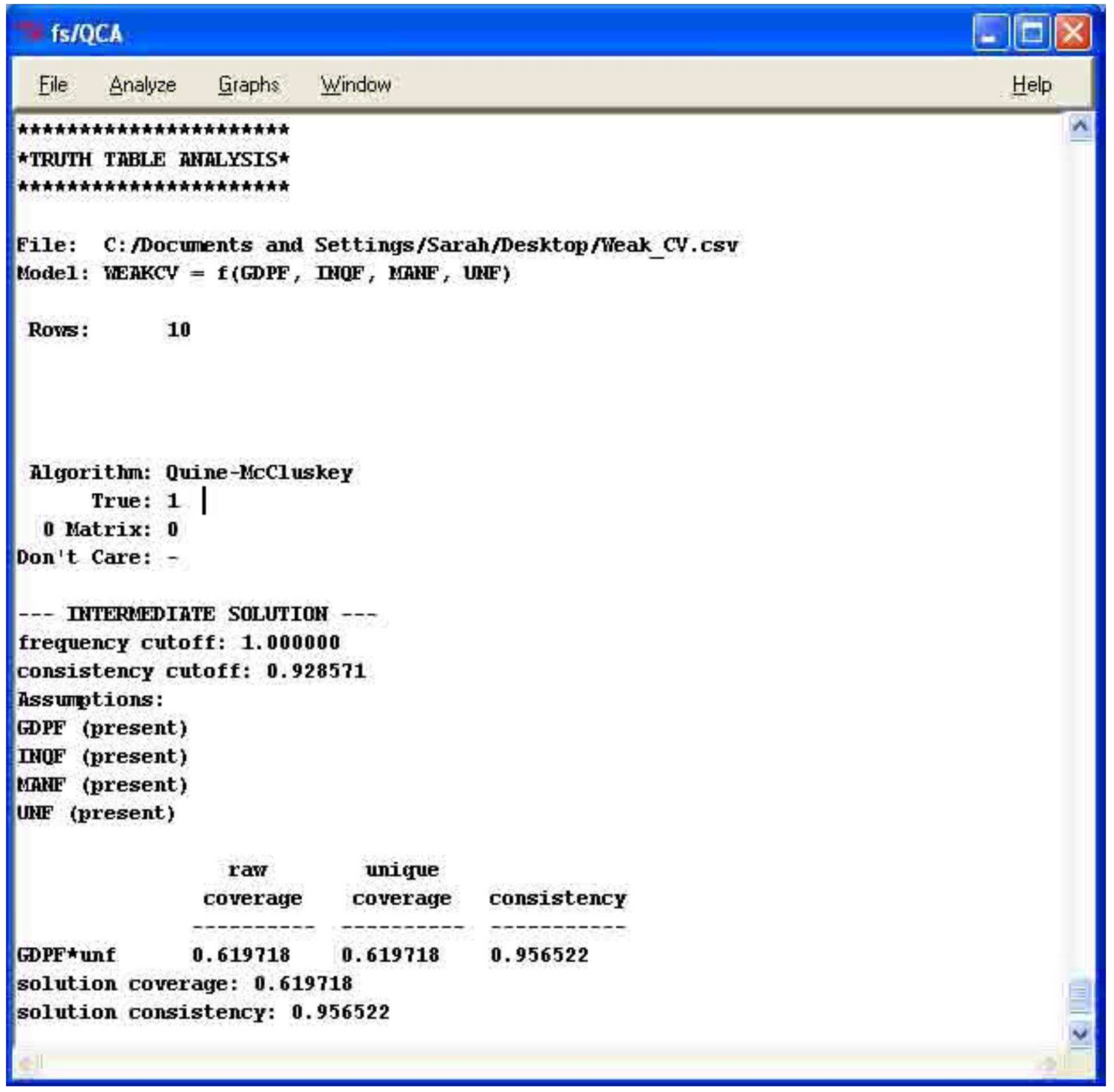


Figure 7: Descriptive statistics

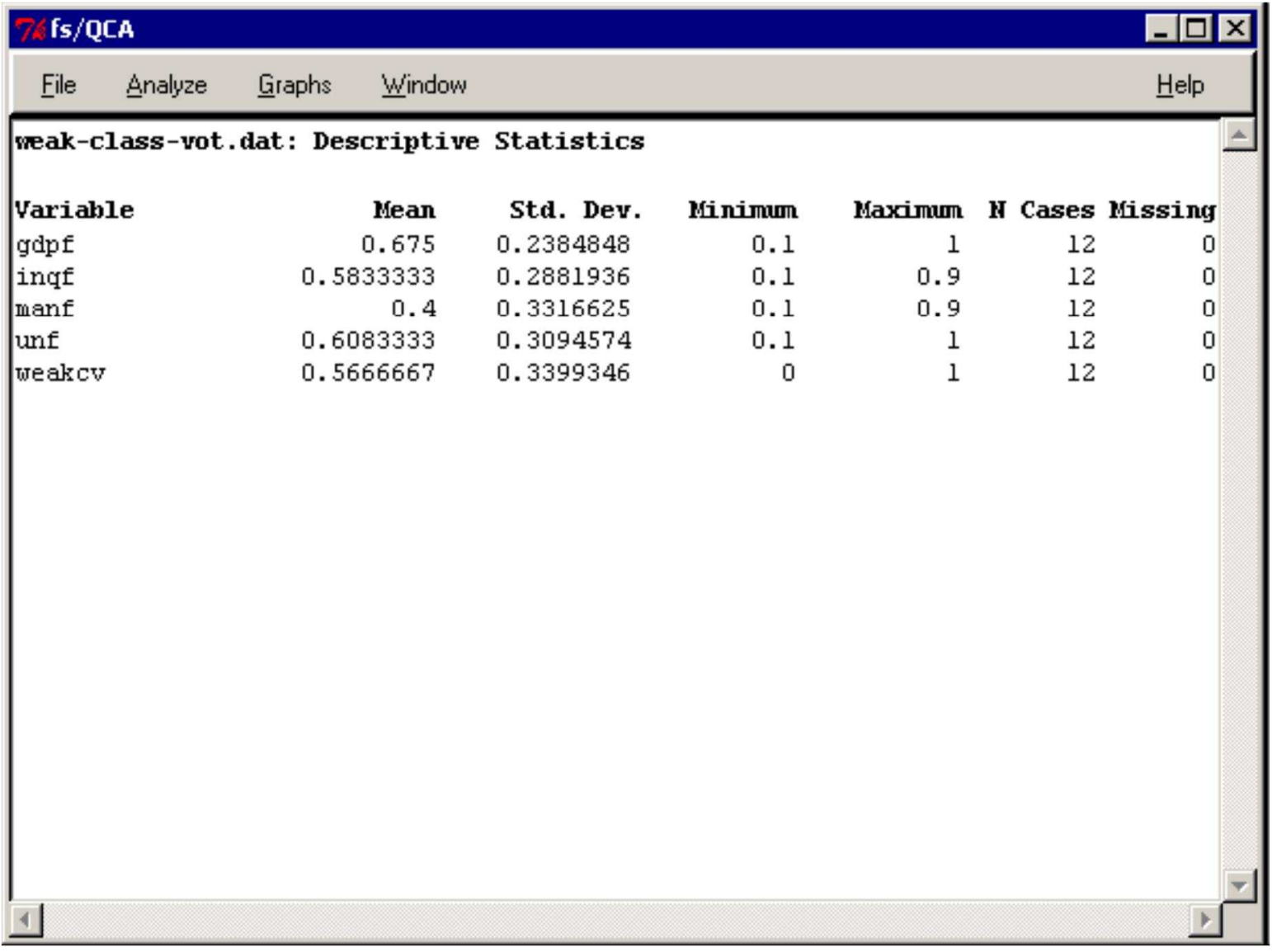

